REVISTA DE DERECHO UNED, NÚM. 17, 2015

\title{
EL AGENTE ENCUBIERTO
}

\author{
THE UNDERCOVER AGENT
}

LOURDES EXPÓSITO LÓPEZ

Fiscal Sustituta. Alumna doctorado de la UNED

Resumen: El grave problema social que representa en la actualidad la criminalidad organizada, requiere la adopción de técnicas especiales de investigación por parte de la policía, para combatir eficazmente este tipo de manifestación criminal. Técnicas que tienen su límite en el sistema de derechos y garantías que la Constitución reconoce a todo imputado. Entre estas técnicas, destaca muy especialmente la figura del agente encubierto o infiltrado, quién actuando bajo identidad supuesta, tiene por finalidad infiltrarse en organizaciones criminales y hacer aflorar conductas delictivas que de otro modo, resultarían imposibles de perseguir. La Jurisprudencia ha analizado en repetidas ocasiones los problemas jurídicos que plantea la admisibilidad, como prueba, de los resultados de su investigación. Es por ello, que su utilización está sometida a rígidos requisitos legales.

Palabras clave: Criminalidad organiza, técnicas de investigación, agente encubierto, identidad supuesta, Infiltración policial.

Abstract: The serious social problem that currently represents organized crime, requires the adoption of special investigative techniques by the police, to effectively combat this type of criminal manifestation. The techniques are limited by the system of rights and guarantees that the Constitution recognizes to all the accused. Among these techniques, stands out especially the figure of undercover or infiltrated agent, who is acting under alleged identity and aims to infiltrate in criminal organizations and bring out criminal behavior that would otherwise be impossible to pursue. The Jurisprudence has re- 
peatedly analyzed the legal challenges of admissibility, as evidence, of the results of their research. It is therefore that its use is subject to strict legal requirements.

Keywords: Organized criminality, skills of investigation, undercover agent, assumed identity, police infiltration.

Recepción original: 26/10/2015

Aceptación original: 04/11/2015

Sumario: I. Consideraciones Previas. II. Regulación jurídica y concepto. III. Sujeto activo en las operaciones de infiltración. IV. Presupuestos de la infiltración policial. V. Autorización para la infiltración. 1. La iniciativa policial. 2. La autorización inicial de la infiltración. A. El juez de instrucción. B. El Ministerio Fiscal. VI. Forma y contenido de la autorización. VII. Duración y prórroga de la infiltración policial. 1. Duración de la infiltración. 2. Prórroga de la infiltración policial. VIII. Extinción de la infiltración. IX. Responsabilidad penal del agente encubierto. X. Conclusiones.

\section{CONSIDERACIONES PREVIAS}

La delincuencia organizada, especialmente en el marco del narcotráfico y el terrorismo, no es un fenómeno de reciente aparición. Las estructuras organizadas, permanentes, con finalidad ilícita y ánimo de lucro, existían con anterioridad al proceso actual de globalización.

No obstante, la mundialización de la economía, ha dado lugar a un proceso de expansión de este tipo de criminalidad traspasando las fronteras nacionales, haciendo ineficaces muchos de los instru mentos de investigación utilizados tradicionalmente por el Estado de Derecho para combatir este tipo de delincuencia ${ }^{1}$.

La Ley Orgánica 5/1999, de 13 de enero², de modificación de la LECrim en materia de perfeccionamiento de la acción investigadora relacionada con el tráfico ilegal de drogas y otras actividades ilícitas graves, recoge, en su Exposición de Motivos:

«La criminalidad organizada ha adquirido en nuestro tiempo una alarmante dimensión, tanto por su importancia, como por el «modus operandi» con que actúa. Ante este nuevo reto, los sucesivos Gobier-

${ }^{1}$ BENÍTEZ ORTÚZAR, I. F. El colaborador con la justicia. Aspectos sustantivos, procesales y penitenciarios derivados de la conducta del «arrepentido», Dykinson, Madrid, 2004, pág. 14.

2 BOE, núm. 12, de 14 de enero de 1999. 
nos han ido poniendo instrumentos de todo orden en manos de quienes tienen la misión de perseguir y reprimir dichas conductas, si bien existen todavía algunos de los que puede dotarse legítimamente un Estado en su lucha contra esas formas de criminalidad que no han tenido acogida en nuestro sistema jurídico».

Y añade: «Las reformas que se incorporan en la presente Ley parten de la insuficiencia de las técnicas de investigación tradicionales en la lucha contra este tipo de criminalidad organizada, que generalmente actúa en ámbitos transnacionales y con abundancia de los medios conducentes a la perpetración de los delitos. De esta forma, se introducen en el ordenamiento jurídico medidas legales especiales que permitan a los miembros de la Policía Judicial participar del entramado organizativo, detectar la comisión de delitos e informar sobre sus actividades, con el fin de obtener pruebas inculpatorias y proceder a la detención de sus autores. Todas estas modificaciones deben introducirse respetando el fin del proceso penal que no es otro que el descubrimiento de la verdad real y la aplicación de la ley penal al caso concreto, teniendo siempre en cuenta que los límites de las técnicas propuestas de investigación se encuentran en el sistema de derechos y garantías que la Constitución reconoce a todo imputado, ya que por más abyectas que sean las formas de delincuencia que se tratan de combatir, ello no justifica la utilización de medios investigadores que pueden violentar garantías constitucionales.

Por tanto, la búsqueda de medios jurídicos eficaces para luchar contra la criminalidad organizada no debe comportar un detrimento de la plena vigencia de los principios, derechos y garantías constitucionales, y la preservación de los aludidos principios, derechos y garantías exige, siempre que exista conflicto, que el mismo se resuelva a favor de estos últimos, porque ellos constituyen el verdadero fundamento de nuestro sistema democrático».

El fenómeno de la criminalidad organizada ha sido tratado ampliamente por la doctrina, tanto penalista como procesalista, quien ha destacado las dificultades para desarticular este complejo entramado organizativo de cara a la prevención y persecución de los delitos que forman parte de su actividad, y al descubrimiento de sus responsables. Tales dificultades se incrementan en la actualidad por el proceso de globalización, a la complejidad de tales redes organizativas, a la gran sofisticación de las tecnologías empleadas y a su clandestinidad ${ }^{3}$.

3 GARCÍA SÁNCHEZ, B. «Técnicas de investigación de la delincuencia organizada: perspectiva penal», en Revista de letras jurídicas, núm. 20, 2004, pág. 2.

(C) UNED. Revista de Derecho UNED, núm. 17, 2015 
Ante estos obstáculos surge la necesidad arbitrar nuevas técnicas de investigación y persecución criminal o perfeccionamiento de las ya existentes, que permita a los órganos encargados de la persecución penal ${ }^{4}$ acceder a la estructura organizativa, detectar la comisión de delitos e informar de sus actividades, con el fin de obtener pruebas inculpatorias y proceder a la detención de sus autores.

En los últimos años, el legislador ha introducido en nuestro ordenamiento procesal penal, nuevas técnicas de investigación y persecución criminal que tiendan a «facilitar la consecución de los elementos incriminatorios que permitan una eficaz represión de las graves conductas delictivas que genera el crimen organizado» ${ }^{5}$. Técnicas como por ejemplo, la vigilancia prolongada de las personas sospechosas de integrar una organización delictiva; la utilización de diversos instrumentos para captar y reproducir la imagen y el sonido; la permisión de la circulación y entrega vigilada de drogas y, muy especialmente, la infiltración de determinadas personas en las organizaciones criminales, lo que se conoce en el ordenamiento jurídico español como agente encubierto regulado en el artículo 282 bis de la Ley de Enjuiciamiento criminal (introducido por la Ley Orgánica 5/1999 de 13 de enero) ${ }^{6}$.

La doctrina destaca de forma unánime ${ }^{7}$ la necesidad de disponer de tales instrumentos de investigación criminal con el fin de evitar la impunidad de todos los sujetos penalmente responsables de delitos que se cometen en el seno de estas estructuras organizativas.

El Derecho Procesal Penal ha ido avanzando en la perfección y sofisticación de sus instrumentos de investigación con el fin de lograr

${ }^{4}$ El artículo 282 de la LECrim establece que la «Policía Judicial tiene por objeto, y será obligación de todos los que la componen, averiguar los delitos públicos que se cometieren en su territorio o demarcación; practicar, según sus atribuciones, las diligencias necesarias para comprobarlos y descubrir a los delincuentes, y recoger todos los efectos, instrumentos o pruebas del delito, de cuya desaparición hubiere peligro, poniéndolos a disposición de la Autoridad Judicial».

${ }^{5}$ GRANADOS PÉREZ, C. «Instrumento procesal en la lucha contra el crimen organizado. Agente Encubierto. Entrega vigilada. El arrepentido. Protección de testigos. Posición de la Jurisprudencia» en La criminalidad organizada. Aspectos sustantivos, procesales y orgánicos, CGPJ, Madrid, 2001, págs. 75 y 76.

6 GARCÍA SÁNCHEZ. Op. cit., pág.3.

7 REY HUIDOBRO, LF. El delito de tráfico de drogas. Aspectos penales y procesales, Tirant lo Blanch, Valencia, 2000, pág. 324; CARMONA SALGADO, C. «La circulación y entrega vigilada de drogas y el Agente encubierto en el marco de la criminalidad organizada sobre narcotráfico» en Estudios jurídico -penales y político- criminales sobre tráfico de drogas y figuras afines, Dykinson, Madrid, 2003, págs. 180 a 181; GÓMEZ DE LIAÑO FONSECA-HERRERO, M. "Límites y Garantías procesales en la investigación mediante agentes encubiertos» en La Ley, 7 de diciembre del 2004, págs. 1 y 2 , entre otros. 
una mayor efectividad y control en la represión de este tipo de criminalidad. El presente trabajo tiene por objeto analizar la figura del agente encubierto atendiendo a su regulación procesal, tras la incorporación en la LECrim del artículo 282 bis.

\section{REGULACIÓN JURÍDICA Y CONCEPTO}

La LO 5 /1999 incorporó el artículo 282 bis de la LECrim dando cobertura legal a la figura del agente encubierto en el ámbito de las investigaciones vinculadas con la delincuencia organizada.

La incorporación de este medio de investigación no significa que no se hubiera utilizado con anterioridad, ya que constituye un «medio histórico de actuación». La novedad consiste en que tradicionalmente no se utilizaba tanto como técnica de investigación procesal, sino como «medio para la obtención de información para los procesos de inteligencia en materia de seguridad $»^{8}$.

El agente encubierto constituye un medio extraordinario de investigación, ya que implica una alteración de los principios constitucionales básicos y una restricción de derechos fundamentales, es por ello que su utilización está condicionada a rígidos requisitos legales ${ }^{9}$. A raíz de su inclusión en la LECrim se trata de dar habilitación legal y posible validez procesal a las pruebas obtenidas mediante esta diligencia policial ${ }^{10}$.

El concepto de agente encubierto es un concepto legal (previsto en el artículo 282 bis LECrim) en la que el «término «agente» se toma en una de sus acepciones, la de "agente policial», y en la que el adjetivo «encubierto «hace referencia a la ocultación de la identidad, condición e intenciones de policía ${ }^{11}$.

La función del agente encubierto se define en el artículo 282 bis. 1 LECrim, por la autorización a funcionarios de la Policía Judicial a «actuar bajo identidad supuesta y a adquirir y trasportar los objetos, efectos e instrumentos del delito y diferir la incautación de los mismos. (...), quedando legítimamente habilitados para actuar en todo lo

${ }^{8}$ SÁNCHEZ TOMÁS, JM. Derecho de las drogas y las drogodependencias, FAD, Madrid, 2002, pág. 214.

${ }^{9} C f r$. MONTON REDONDO, A/BARONA VILAR, S. et al. Derecho Jurisdiccional III. Proceso Penal, 9. a edición, Tirant Lo Blanch, Valencia, 2000, pág. 207.

${ }^{10}$ SÁNCHEZ TOMÁS. Op. cit., pág. 214.

11 GASCÓN INCHAUSTI, F. Infiltración policial y «agente encubierto», Comares, Granada, 2001, pág. 14. 
relacionado con la investigación concreta y a participar en el tráfico jurídico y social bajo tal identidad».

De este modo, se posibilita el «otorgamiento y la utilización de una identidad supuesta a funcionarios de la Policía Judicial, que puede mantenerse en el eventual proceso judicial posterior», con lo que se completa el régimen de protección que incorporaba la LO 19/1994, de 23 de diciembre, respecto a los peritos y testigos en las causas criminales ${ }^{12}$.

La condición de agente encubierto sólo pueden ostentarla funcionarios de la Policía Judicial ${ }^{13}$ (art. 282 LECrim y art. $11 \mathrm{~g}$ ) de la LO 2/1986, de 13 de marzo, de Fuerzas y Cuerpos de Seguridad), encomendándoles a los agentes la función de investigar los delitos, y descubrimiento y persecución de los presuntos culpables ${ }^{14}$, poniéndolos a disposición de la autoridad judicial

Esta figura es empleada como medio para infiltrase ${ }^{15}$ en organizaciones delictivas y obtener elementos probatorios contra personas involucradas en la comisión de alguno de los delitos que enumera el precepto $^{16}$, es por ello, por lo que también se le denomina «agente infiltrado", desempeñando un papel que haga suponer que se trata de uno de los integrantes de la organización, lo que le posibilita obtener información o elementos probatorios para evitar la comisión de la actividad criminal o sancionarla una vez cometido ${ }^{17}$.

Como manifiesta GASCÓN INCHAUSTI lo fundamental de toda operación de infiltración es la «ocultación de la identidad» y de los "propósitos del infiltrado» como punto de inicio, con lo que se logra con el paso del tiempo una relación de confianza que le facilita la obtención de información; es decir, "el engaño y el abuso de confianza» ${ }^{18}$.

12 CHOClán MONTALVO, JA. La Organización Criminal. Tratamiento penal y procesal, Dykinson, Madrid, 2001, pág. 61.

13 GÓMEZ DE LIAÑO FONSECA-HERRERO. Op. cit., pág. 131.

${ }^{14}$ STS Sala 2. ${ }^{\text {a }}$, núm., 1458/2004, de 3 de marzo.

15 Se puede definir la infiltración como «la acción de aquél que, para obtener una información que no es de acceso general y que le es necesaria para un propósito concreto, oculta tanto su identidad real como sus intenciones y, bien directamente, bien a través de un tercero, entra en contacto con las personas aparentemente susceptibles de suministrársela, estableciendo con ellas una falsa relación de confianza que, con el trascurso del tiempo, le permita obtener la información deseada». GASCÓN INCHAUSTI. Op. cit., pág. 10.

16 STS Sala 2. ${ }^{a}$, núm. 508/2001, de 29 de enero.

17 STS Sala 2. ${ }^{\text {, }}$, núm. 4287/2002, de 12 de junio.

18 GASCÓN INCHAUSTI. Op. cit., pág. 10. 
Para introducirse en la organización delictiva se puede emplear cualquier actuación imaginable, siempre que no se vulnere los derechos constitucionales de los sujetos investigados ${ }^{19}$.

Igualmente, se concreta a estos efectos el concepto de delincuencia organizada, delimitando los tipos penales que comprende y finalmente, se autoriza al agente encubierto para utilizar, bajo un rígido control del Juez y Fiscal, instrumentos complementarios de investigación ${ }^{20}$.

En cualquier caso, los riesgos que implican la ejecución de estas técnicas de investigación justifican que la aceptación de la misión sea voluntaria para el funcionario de la Policía Judicial (art. 282 bis) ${ }^{21}$.

De lo expuesto, se puede concluir que la figura del agente encubierto es un «instrumento al servicio de una técnica de investigación propia de la fase de instrucción del proceso penal: la infiltración policial». La previsión legal del instrumento conlleva, la admisión de la técnica. El precepto legal regula simultáneamente tanto la técnica de investigación como el instrumento ${ }^{22}$.

El artículo 282 bis de la LECrim, incorporado al Título de la Policía Judicial, dispone:

1. A los fines previstos en el artículo anterior y cuando se trate de investigaciones que afecten a actividades propias de la delincuencia organizada, el Juez de instrucción competente o el Ministerio Fiscal, dando cuenta inmediata al Juez, podrán autorizar a funcionarios de la Policía Judicial, mediante resolución fundada y teniendo en cuenta su necesidad a los fines de la investigación, a actuar bajo identidad supuesta y a adquirir y trasportar los objetos, efectos e instrumentos del delito y diferir la incautación de los mismos. La identidad supuesta será otorgada por el Ministerio del Interior por el plazo de seis meses prorrogables por períodos de igual duración, quedando legítimamente habilitados para actuar en todo lo relacionado con la investigación concreta y a participar en el tráfico jurídico y social bajo tal identidad.

La resolución por la que se acuerde deberá consignar el nombre verdadero del agente y la identidad supuesta con la que actuará en el caso concreto. La resolución será reservada y

19 STS Sala 2. ${ }^{\text {a }}$, núm. 7815/2007, de 15 de noviembre.

${ }^{20}$ GRANADOS PÉREZ. Op. cit., pág. 88.

${ }^{21}$ CHOCLÁN MONTALVO. Op. cit., pág. 62.

22 GASCÓN INCHAUSTI. Op. cit., pág. 17. 
deberá conservarse fuera de las actuaciones con la debida seguridad.

La información que vaya obteniendo el agente encubierto deberá ser puesta a la mayor brevedad posible en conocimiento de quién autorizó la investigación. Asimismo, dicha información deberá aportarse al proceso en su integridad y se valorará en conciencia por el órgano judicial competente.

2. Los funcionarios de la Policía Judicial que hubieran actuado en una investigación con identidad falsa de conformidad a lo previsto en el apartado 1, podrán mantener dicha identidad cuando testifiquen en el proceso que pudiera derivarse de los hechos en que hubiera intervenido, y siempre que así se acuerde mediante resolución judicial motivada, siéndole también de aplicación lo previsto en la Ley Orgánica 19/1994, de 23 de diciembre. Ningún funcionario de la Policía Judicial podrá ser obligado a actuar como agente encubierto.

3. Cuando las actuaciones de investigación puedan afectar a derechos fundamentales, el agente encubierto deberá solicitar del órgano judicial competente las autorizaciones que al respecto establezca la Constitución y la Ley, así como cumplir las demás previsiones legales aplicables.

4. A los efectos señalados en el apartado primero de este artículo, se considerará como delincuencia organizada la asociación de tres o más personas para realizar, de forma permanente o reiterada, conductas que tengan como fin cometer alguno o algunos de los delitos siguientes:

a) Delitos de obtención, tráfico ilícito de órganos humanos y trasplante de los mismos, previstos en el artículo 156 bis del Código Penal.

b) Delito de secuestro de personas previsto en los artículos 164 a 166 del Código Penal.

c) Delitos de trata de seres humanos previsto en el artículo 177 bis del Código Penal.

d) Delitos relativos a la prostitución previstos en los artículos 187 a 189 del Código Penal.

e) Delitos contra el patrimonio y el orden socioeconómico previstos en los artículos 237, 243, 244 y 301 del Código Penal.

f) Delitos relativos a la propiedad intelectual e industrial previstos en los artículos 270 a 277 del Código Penal. 
g) Delitos contra los derechos de los trabajadores previstos en los artículos 312 y 313 del Código Penal.

h) Delitos contra los derechos de los ciudadanos extranjeros previstos en el artículo 318 bis del Código Penal.

i) Delitos de tráfico de especies de flora o fauna amenazada previsto en los artículos 332 y 334 del Código Penal.

j) Delito de tráfico de material nuclear y radiactivo previsto en el artículo 345 del Código Penal.

k) Delitos contra la salud pública previstos en los artículos 368 a 373 del Código Penal.

1) Delitos de falsificación de monedas, previsto en los artículos 386 del Código Penal, y de falsificación de tarjetas de crédito o débito o cheques de viaje, previsto en el artículo 399 bis del Código Penal.

m) Delito de tráfico y depósito de armas, municiones o explosivos previsto en los artículos 566 a 568 del Código Penal.

n) Delitos de terrorismo previsto en los artículos 572 a 578 del Código Penal.

o) Delitos contra el patrimonio histórico previstos en el artículo 2.1.e) de la Ley Orgánica 12 /1995, de 12 de diciembre, de represión del contrabando.

5. El agente encubierto está exento de responsabilidad criminal por aquellas actuaciones que sean consecuencia necesaria del desarrollo de la investigación, siempre que guarden la debida proporcionalidad con la finalidad de la misma y no constituyan una provocación del delito.

Para poder proceder penalmente contra el mismo por las actuaciones realizadas a los fines de la investigación, el Juez competente para conocer de la causa deberá, tan pronto tenga conocimiento de la actuación de algún agente encubierto en la misma, requerir informe relativo a tal circunstancia de quién hubiere autorizado la identidad supuesta, en atención al cual resolverá lo que a su criterio proceda.

El artículo 282 bis establece una regulación en la que se abordan dos aspectos importantes, en primer lugar, los presupuestos para la adopción de esta medida y su forma de ejecución; y en segundo lugar, el estatuto de responsabilidad y protección del agente encubierto ${ }^{23}$.

${ }^{23}$ SÁNCHEZ TOMÁs. Op. cit., pág. 214. 


\section{SUJETO ACTIVO EN LAS OPERACIONES DE INFILTRACIÓN}

Los únicos legitimados para actuar como agentes encubiertos son los miembros de la Policía Judicial (art. 282 bis LECrim). Lo que significa que ningún sujeto que no pertenezca a las Fuerzas y Cuerpos de Seguridad del Estado no podrá realizar dicha tarea.

Por otro lado, ningún policía tiene la obligación de intervenir como agente encubierto. Pues, el artículo 282 bis. 3 dispone: «ningún funcionario de la Policía Judicial podrá ser obligado a actuar como agente encubierto».

La Policía Judicial ${ }^{24}$ es definida como «una función específica dentro de las funciones de la Policía General, basada en los criterios de la Policía científica, destinada a la investigación de los hechos punibles, la persecución y aseguramiento de los delincuentes, poniendo a disposición de la autoridad judicial y eventualmente, del Ministerio Fiscal, los resultados de su averiguación» ${ }^{25}$.

Desde esta perspectiva la función de Policía Judicial no es sino la función de policía criminal represiva o encaminada a la represión de las infracciones criminales ${ }^{26}$. Para MORENO CATENA la Policía Judicial es una Policía para el enjuiciamiento penal, desarrollando sus funciones en el proceso penal, con el objeto de perseguir y castigar los hechos delictivos, bien mediante actuaciones preliminares a la intervención judicial, bien mediante diligencias practicadas durante el proceso $^{27}$.

Si bien, se exige que la actuación policial esté marcada por el respeto a los principios constitucionales de «dignidad de la persona y a su libre y espontánea determinación, y se prohíbe toda acción coactiva sobre la voluntad ajena, así como la utilización de medios ilícitos o éticamente reprobables, aunque su finalidad fuera la de llegar a lograr la mayor efectividad en el cumplimiento de las leyes atinentes a la

${ }^{24}$ La normativa española sobre la Policía Judicial la constituyen: el artículo 126 de la CE, los artículos 547 a 550 de la LOPJ, el Título III del Libro II de la LECrim, los artículos 29 a 36 de la LO 2/1986 de 13 de marzo, de Fuerzas y Cuerpos de Seguridad del Estado (LOFCSE), y especialmente, el Real Decreto 769/1987, de 19 de junio, sobre Policía Judicial (RDPJ)

${ }_{25}$ QUERÁLT JIMÉNEZ, J. Introducción a la Policía Judicial, 3. ${ }^{a}$ edición, Bosch, Barcelona, 1999, pág. 13.

${ }^{26}$ LLERA SÚAREZ BÁRCENA, E. El modelo constitucional de investigación penal, Tirant Lo Blanch, Valencia, 2001, pág. 333.

27 MORENO CATENA, V. «Dependencia orgánica y funcional de la Policía Judicial» en Revista del Poder Judicial, núm. Especial VIII (Seguridad ciudadana), 1989, pág. 143. 
represión y prevención de la delincuencia» ${ }^{28}$. Por tanto, se exige la absoluta legalidad tanto para los medios, como para los fines.

El cuerpo de Policía Judicial está integrado en el Cuerpo Nacional de Policía, estructurado en diversas unidades especializadas en criminalidad organizada. Esta especialización es consecuencia de las sofisticadas técnicas empleadas para delinquir. Surgiendo también nuevas técnicas operativas en el descubrimiento y persecución de esta compleja delincuencia, que requiere cuerpos especializados ${ }^{29}$.

De lo expuesto, resulta evidente la necesidad y efectividad de la Policía Judicial como institución estatal encargada de mantener la seguridad frente a las actuaciones delictivas de las organizaciones criminales $^{30}$. Es innegable que un particular no podría actuar como agente encubierto, al carecer de los conocimientos, experiencia y condiciones físicas y psicológicas para infiltrarse en el complejo y peligroso entramado de una organización criminal ${ }^{31}$.

El Estado no puede asumir el riesgo de que los particulares actúen como agentes infiltrados en organizaciones delictivas, vulnerando derechos fundamentales, y originando la nulidad de la información obtenida durante la investigación, y frustrándose las expectativas de declarar responsables a los investigados por no haber logrado la enervación de la presunción de inocencia ${ }^{32}$.

Respecto a los integrantes del Cuerpo Nacional de Inteligencia regulado por la Ley $11 / 2002$, de 6 de mayo ${ }^{33}$, reguladora del Centro

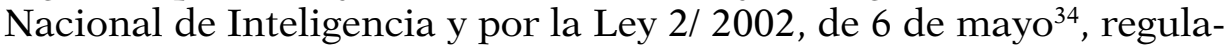
dora del control judicial previo del Centro Nacional de Inteligencia, su cometido es informar al Gobierno en todo lo que puede afectar a la

28 STS Sala 2. ${ }^{\text {a }}$, núm. 953/ 1991, de 20 de febrero.

29 ESPINOSA DE LOS MONTEROS, RZ. «El agente encubierto en el ordenamiento jurídico español», en La prueba en el espacio europeo de libertad, seguridad y justicia penal, Aranzadi, 2006, pág. 238.

30 GÓMEZ DE LIAÑO FONSECA-HERRERO. Op. cit., pág. 103.

31 Vid. ESPINOSA DE LOS MONTEROS, RZ. El policía infiltrado. Los presupuestos jurídicos en el proceso penal español, Tirant lo Blanch, Valencia, 2010, pág. 233, señala que por esta razón: "hay que estimar que cuando un agente entra en el entramado organizativo son muchas las posibilidades de que tenga que cometer delitos, de que tenga que consumir drogas, lo que supone un riesgo inmenso para un particular no preparado».

32 Ibídem, pág. 79. Continúa la autora señalando que: «La participación en la investigación penal realizando labores de infiltración, se deben calificar como infiltraciones semipúblicas o infiltraciones sobrevenidas practicadas por los confidentes y arrepentidos con el consentimiento y bajo el control y dirección de los poderes públicos».

33 BOE núm. 109 /2002, de 7 de mayo.

34 BOE núm. 109 /2002, de 7 de mayo. 
seguridad, estabilidad y defensa de un Estado en materia de delincuencia organizada.

Pueden asumir el rol de agentes secretos, siendo diferenciables de los agentes encubiertos en cuanto que no se encuentran amparados en el artículo 282 bis LECrim y además no ostentan la condición de autoridad $^{35}$. Tampoco ostentan funciones de poder de Policía Judicial que les legitima para la obtención de elementos probatorios con el fin de aportarlos al proceso penal y acreditar los hechos investigados ${ }^{36}$. Su naturaleza y funciones están totalmente alejadas del ámbito del proceso penal ${ }^{37}$.

En conclusión, sólo podrán desempeñar funciones de agente encubierto aquellos miembros de la policía con entrenamiento y preparación específica para actuar en el ámbito criminal. Siendo agentes especialmente seleccionados para actuar dentro del marco legal vigente y a largo plazo, para combatir actividades delictivas organizadas, manteniendo su identidad secreta durante la operación de infiltración, con el fin de garantizar su seguridad y obtener pruebas para aportar al proceso penal ${ }^{38}$.

\section{PRESUPUESTOS DE LA INFILTRACIÓN POLICIAL}

Los presupuestos que habilitan la adopción de este mecanismo de investigación son la concurrencia de "proporcionalidad, necesidad y racionalidad de la situación ${ }^{39}$, lo que exige:

1. Que se trate de investigaciones que afecten a actividades propias de la delincuencia organizada. Es decir, que se trate de actividades delictivas cometidas de forma organizada.

Del precepto se deduce que, cuando existan indicios racionales de la comisión de un delito propio de la delincuencia organizada, se podrá autorizar la infiltración de un funcionario de la Policía Judicial en el seno de la organización, para investigarla y obtener elementos de prueba que permitan impedir o sancionar la actividad delictiva, e incluso desarticular la organización ${ }^{40}$.

35 ESPINOSA DE LOS MONTEROS. «El agente...», cit., pág. 239.

${ }^{36}$ DELGADO MARTÍN, J. La criminalidad organizada. Comentarios a la Ley 5/1999 de 23 de febrero, Bosch, Barcelona, 2001, pág. 66.

${ }^{37}$ GASCÓN INCHAUSTI. Op. cit., pág. 17.

38 MONTOYA, MD. Informantes y técnicas de investigación encubiertas. Análisis

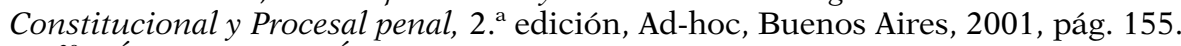

39 SÁNCHEZ TOMÁS. Op. cit., pág. 214.

40 STS Sala 2. ${ }^{a}$, núm. 843/ 2007, de 25 de enero; STS Sala 2. ${ }^{\text {, }}$ núm. 7815/2007, de 15 de noviembre. 
Evidentemente, los indicios existentes sobre la comisión de la actividad delictiva organizada, deben ser suficientemente verosímiles y fiables, y por otro lado, concretos como para señalar «hacia dónde debe dirigirse el infiltrado» ${ }^{41}$.

Comprobada la veracidad de la información relativa a la comisión de una actividad delictiva organizada, los funcionarios de la Policía Judicial que dirijan la investigación solicitarán la adopción de la medida, previa elaboración de los informes oportunos en los que se expondrán los indicios que acrediten que se trata de una organización delictiva, que dirigirán al órgano competente a efectos de valorar la necesidad y proporcionalidad de la medida ${ }^{42}$.

El término «organización» fue añadido por el CP de 1995 al de asociación, para hacer referencia a la criminalidad organizada o de "cuello blanco», aunque se trata de un concepto normativo, dado que el Código carece de una definición concreta de ambos términos ${ }^{43}$.

No obstante, el artículo 284 bis. 4 de la LECrim realiza una interpretación legal del término "delincuencia organizada». Por primera vez en nuestra legislación, el propio precepto establece, los requisitos necesarios para poder apreciar la existencia de organización delictiva. Estos requisitos son:

1. ${ }^{\circ}$ La asociación de tres o más personas.

2. ${ }^{\circ}$ Actividad permanente o reiterada.

3..$^{\circ}$ Realización de alguno o algunos de los delitos enumerados taxativamente en el apartado cuarto del precepto.

2. Que la finalidad de la medida sea la obtención de elementos probatorios para la investigación, que no puedan obtenerse por otro medio.

Para la utilización de esta medida se requiere que concurra un fin legítimo que justifique la invasión del poder público en la esfera de los derechos y libertades de los ciudadanos ${ }^{44}$.

La finalidad de la medida debe ser el descubrimiento de los responsables de la organización delictiva y la obtención de elementos probatorios para su aportación al proceso penal ${ }^{45}$, con lo que se ga-

${ }^{41}$ GASCÓN INCHAUSTI. Op. cit., pág. 123.

42 MOLINA MANSILLA. Op. cit., págs. 32 y 33.

43 STS Sala 2. a, núm. 2519/2007, de 4 de abril.

${ }^{44}$ GASCÓN INCHAUSTI. Op. cit., pág. 112.

45 SÁNCHEZ TOMÁS. Op. cit., pág. 214. 
rantiza su éxito; con lo que se alcanza de modo general, la persecución penal del delito y se garantiza la paz jurídica ${ }^{46}$.

Por tanto, constituye un fin legítimo equiparable a la protección de los derechos y principios que se ven amenazados, en principio, por la infiltración policial. Se trata, de una manifestación más del «eterno debate entre individuo y Estado, entre proceso penal eficaz (pero, eso sí, legítimo) y respeto a la legalidad y a los derechos fundamentales ${ }^{47}$.

No obstante, es una medida excepcional que sólo podrá otorgarse cuando no exista un mecanismo menos lesivo para los derechos fundamentales del investigado.

Además, esta técnica impone una cláusula de salvaguardia de los derechos del individuo, ya que el párrafo tercero del artículo 282 bis LECrim dispone que cuando las actuaciones policiales afecten a los derechos fundamentales de los investigados, el agente infiltrado deberá solicitar la autorización del órgano judicial ${ }^{48}$.

3. Que sea necesaria a esos fines de la investigación organizada.

La figura del agente encubierto, como medida de carácter excepcional, exige que el órgano autorizante valore con cautela su necesidad para los fines de la investigación. Lo que implica «la debida ponderación y la razonabilidad de la medida en atención a las dificultades de investigación por otros medios (cláusula de subsidiariedad) ${ }^{49}$.

La medida debe ser necesaria a los fines de la investigación, en relación con la importancia del delito y las posibilidades de la vigilancia, en el marco de un procedimiento penal ${ }^{50}$.

Además, el criterio de la necesidad «obliga a los órganos del Estado a comparar las medidas restrictivas aplicables que sean suficientemente aptas para la satisfacción del fin perseguido y a elegir, finalmente, aquélla que sea menos lesiva para los derechos de los ciudadanos $»^{51}$.

El legislador español ha recogido de forma expresa en el texto legal la exigencia de la necesidad de la medida a la hora de autorizarla en un caso concreto.

46 GASCÓN INCHAUSTI. Op. cit., pág. 113.

${ }^{47}$ MORENO CATENA, V. «Garantía de los derechos fundamentales en la investigación penal» en Poder Judicial, Número Especial 2 (Justicia Penal), 1987, págs. 131 y ss.

48 MOLINA MANSILLA. Op. cit., pág. 32.

49 CHOCLÁN MONTALVO. Op. cit., pág. 63.

50 STS Sala 2. ${ }^{\text {, }}$ núm. 1979/2007, de 28 de febrero.

51 GÓNZALEZ-CUÉLLAR SERRANO, N. Proporcionalidad y derechos fundamentales en el proceso penal, Colex, Madrid, 1990, pág. 189. 
Así, el artículo 282 bis. 1 de la LECrim, establece que la medida será adoptada «teniendo en cuenta su necesidad a los fines de la investigación», lo que, en opinión de GASCÓN INCHAUSTI significa una prohibición de recurrir a ella en los supuestos en los que sea posible alcanzar la misma finalidad, mediante un mecanismo menos lesivo ${ }^{52}$.

4. Que sea proporcionada a los fines que se pretende alcanzar con ella.

Lo que significa que la adopción de la medida no implique «una lesión excesiva sobre el derecho afectado» es decir, debe darse una correlación adecuada entre «la intensidad del ataque al derecho y el resultado que con ello se obtiene ${ }^{53}$.

Los elementos de juicio que deben tenerse en cuenta al valorar la proporcionalidad son $^{54}$ :

a. La gravedad de los delitos para cuya investigación se autoriza. Ha de tratarse de un de un delito grave, de los enumerados en el apartado 4 del artículo 282 bis LECrim, no sólo en el ámbito penal por la aplicación de una pena privativa de libertad grave, sino también por la trascendencia social del delito y la entidad del bien jurídico lesionado ${ }^{55}$.

b. La duración temporal de la medida. Una duración excesiva de esta medida puede ser desproporcionada a los fines que se persiguen alcanzar con ella. El respeto al principio de proporcionalidad exige que la duración de la medida se reduzca a lo mínimo imprescindible para el éxito de la persecución penal. En este sentido, el precepto legal merece un juicio favorable en cuanto que cabe deducir del mismo, una duración máxima inicial de seis meses para la medida, prorrogables por periodos de igual extensión.

c. La amplitud de las facultades que se le concede al agente policial en el desempeño de sus funciones como infiltrado. También, en este sentido, el texto legal contiene indicios favorables a la proporcionalidad:

1. El párrafo tercero del artículo 282 bis. 1 obliga al agente encubierto a dar cuenta a la autoridad que hubiese autorizado

${ }^{52}$ GASCÓN INCHAUSTI. Op. cit., pág. 131.

53 GONZALEZ CUÉLLAR SERRANO. Op. cit., pág. 225.

${ }^{54}$ GASCÓN INCHAUSTI. Op. cit., págs. 133 y ss.

55 STS Sala 2. ${ }^{\text {a }}$, núm. 1630/2007, de 28 de febrero; STS Sala 2. ${ }^{a}$, núm. 2519 /2007, de 4 de abril. 
su infiltración, de la información que vaya obteniendo, y ello "a la mayor brevedad posible», lo que favorece el control judicial de la eficacia de la medida, siendo éste imprescindible para dar validez a las pruebas obtenidas por el agente $^{56}$.

2. El apartado tercero establece la necesidad de que el agente solicite autorización judicial de forma individualizada para las actividades de investigación que pueden afectar a derechos fundamentales.

3. La exención de responsabilidad penal del agente encubierto que se dispone en el apartado 5, se hace depender de las posibles infracciones que guarden proporcionalidad con los fines de la investigación, y no constituyan una provocación del delito.

4. En relación con lo anterior, cabe señalar que la provocación del delito por el agente encubierto, supondría extralimitación de sus funciones de investigación, y por tanto, se infringiría el principio de proporcionalidad en sentido estricto.

d. El destino de la información obtenida a través de la infiltración. No se admite, por desproporcionado, que la información obtenida por el agente encubierto mediante su infiltración, se utilice con una finalidad diferente a aquélla que originó su autorización. El párrafo tercero del artículo 282 bis.1 dispone que «dicha información deberá aportarse al proceso en su integridad y se valorará en conciencia por el órgano judicial competente».

\section{Que la intervención esté sujeta al principio de especialidad}

La autorización de la medida sólo se realizará cuando se trate de alguno o algunos de los delitos enumerados taxativamente en el apartado cuarto del artículo 282 bis, sin que pueda autorizarse de forma mecánica, ante cualquier solicitud de la Policía Judicial ${ }^{57}$. Por tal motivo, no resultan lícitas las observaciones realizadas sobre una persona en general, requiriéndose por el contrario la suficiente identificación del sospechoso ${ }^{58}$.

${ }^{56}$ MOLINA MANSILLA. El delito..., cit., pág. 302.

57 MOLINA MANSILLA. Mecanismos..., cit., pág. 32.

58 STS Sala 2 . $^{\text {, }}$ núm. 1979/2007, de 28 de febrero. 


\section{AUTORIZACIÓN PARA LA INFILTRACIÓN}

\section{La iniciativa policial}

La infiltración policial presupone la realización de una actividad investigadora ante la existencia de indicios racionales de la comisión de una actividad delictiva organizada, en cuyo marco se considera adecuado la utilización de uno o varios agentes encubiertos. Esta operación previa corresponde a la Policía Judicial.

Una vez llegue a conocimiento de la Policía Judicial la existencia de indicios de la comisión de una actividad delictiva organizada, y se haya comprobado la veracidad de la información y las posibilidades de éxito de este mecanismo, corresponde a los mandos policiales responsables de la investigación solicitar su aplicación. Para ello, se elaborarán los informes oportunos, en los que se expondrán los indicios que acrediten que se trata de una organización delictiva, siendo entregados al órgano competente, con el fin de valorar la necesidad y proporcionalidad de la medida ${ }^{59}$.

La iniciativa para proceder a una infiltración corresponde a la Policía Judicial al disponer de la cualificación y conocimientos para preparar una operación de este alcance, y para valorar las posibilidades de éxito de la infiltración ${ }^{60}$.

Sin embargo, atendiendo a los valores comprometidos mediante esta técnica, la Policía Judicial no es competente para ponerla en práctica, debiendo solicitarse autorización expresa del Juez de Instrucción o del Ministerio Fiscal (art. 282 bis.1 LECrim).

La iniciativa policial no se establece de forma expresa en el texto legal, pero se infiere de lo que sucede en la práctica ${ }^{61}$.

También, se puede deducir indirectamente del texto legal en cuanto se les otorga al Juez de Instrucción y al Ministerio Fiscal el poder de «autorizar» pero no de «decidir». Estos órganos pueden sugerir a la Policía Judicial que realice un estudio sobre la viabilidad de la infiltración en un caso concreto, pero no ordenar a la Policía que diseñen una operación encubierta, ni a un funcionario de la policía que se infiltre y actúe como agente encubierto ${ }^{62}$.

\footnotetext{
59 MOLINA MANSILLA. Mecanismos..., cit., págs. 31 y 32 .

60 DEL POZO PÉREZ. Op. cit., pág. 282.

${ }^{61}$ GÓMEZ DE LIAÑO FONSECA-HERRERO. Op. cit., pág. 173.

${ }^{62}$ GASCÓN INCHAUSTI. Op. cit., pág. 186.
} 
Esto último puede deducirse del párrafo segundo del apartado segundo del artículo 282 bis LECrim que dispone «ningún funcionario de la Policía Judicial podrá ser obligado a actuar como agente encubierto».

Por otra parte, que la iniciativa para la infiltración corresponda a la Policía Judicial, no implica la exclusión de una investigación oficial bajo la dirección del Juez de Instrucción o Ministerio Fiscal (en el ámbito de la investigación preliminar) ${ }^{63}$.

Ciertamente, la autonomía de la Policía Judicial en la investigación de actividades delictivas se limita, fundamentalmente, a las diligencias de prevención del artículo $13 \mathrm{LECrim}^{64}$, y a las diligencias de comprobación que puede realizar por sí la Policía tras recibir una denuncia, y antes de elaborar y presentar, en su caso, el correspondiente atestado al Juez de Instrucción o al Ministerio Fiscal.

Teniendo en cuenta estas limitaciones, son dos los marcos inherentes a la infiltración policial ${ }^{65}$ :

a) En una instrucción abierta (a cargo del Juez, o en su caso del Fiscal, dentro de los límites de su competencia).

b) En su apertura al tiempo de autorizar o confirmar la medida (cuando haya sido autorizada por el Fiscal en el ámbito de unas diligencias preliminares practicadas bajo su dirección).

\section{La autorización inicial de la infiltración}

Una vez que la Policía Judicial ha valorado la necesidad de realizar una investigación encubierta, el texto legal exige una autorización para darle inicio formal a la infiltración, atribuyéndole la competencia para tal autorización inicial no sólo al Juez de Instrucción competente, sino también al Ministerio Fiscal «dando cuenta inmediata al juez ${ }^{66}$.

${ }^{63}$ MORENO CATENA. «Los agentes encubiertos en España» en Otrosí, núm. 10, 1999, pág. 42.

${ }^{64}$ ORTELLS RAMOS, M. "Problemas de contenido y delimitación de las fases del proceso abreviado (diligencias previas, fase intermedia, juicio oral» en El proceso penal abreviado (Nueve estudios), Comares, Granada, 1997, pág. 108.

${ }_{65}$ GIMENO SENDRA, V et al. Derecho Procesal Penal, 3. ${ }^{\mathrm{a}}$ edición, Colex, Madrid, 1999, pág. 408.

${ }^{66}$ GÓMEZ DE LIAÑO FONSECA-HERRERO. Op. cit., pág. 181. 
El apartado primero del artículo 282 bis. LECrim contiene, por tanto, una «doble, indistinta e indiferente, competencia en la autorización inicial de la investigación ${ }^{67}$.

Establece que el Juez de Instrucción competente o el Ministerio fiscal, mediante resolución fundada y teniendo en cuenta su necesidad a los fines de la investigación, podrán autorizar a funcionarios de la Policía Judicial a actuar bajo una identidad supuesta. Por tanto, las Autoridades competentes para autorizar la adopción de esta medida son el Juez de Instrucción o el Ministerio Fiscal, no disponiendo de esta facultad la Autoridad Administrativa, a diferencia de lo establecido para la técnica de la entrega vigilada del artículo 263 bis LECrim ${ }^{68}$.

\section{A. El Juez de Instrucción}

La autorización judicial para la aplicación de este mecanismo de investigación corresponde al Juez de Instrucción, ya que es él el que ostenta la dirección del proceso penal, así como la restricción de los derechos fundamentales de esta medida.

Es imprescindible que la adopción de una medida que pueda implicar una limitación de los derechos fundamentales en el proceso penal proceda siempre de un juez, dado que corresponde al Poder Judicial garantizar el cumplimiento y el respeto de los mismos ${ }^{69}$.

El texto legal hace referencia explícita a que la autorización se solicite del «Juez de Instrucción competente» (art. 282 bis.1 LECrim). Por Juez de Instrucción competente, debe entenderse:

a. El que este conociendo de la causa incoada en el momento de la solicitud.

b. Aquél a quien corresponda instruir los delitos sujetos a investigación mediante la infiltración, cuando el proceso penal no se haya incoado, y la solicitud, sea consecuencia de unas investigaciones preliminares realizadas por la Policía Judicial ${ }^{70}$.

En ambos supuestos, ha de tenerse en cuenta la posible competencia de los Juzgados Centrales de Instrucción cuando los delitos sujetos a investigación son delitos de terrorismo (art. 65.1.a) LOPJ), de

67 GASCÓN INCHAUSTI. Op. cit., pág. 189.

${ }^{68}$ MOLINA MANSILLA. Mecanismos..., cit., pág. 31.

69 GONZÁLEZ CUÉLLAR SERRANO. Op. cit., pág. 117.

${ }^{70}$ GASCÓN INCHAUSTI. Op. cit., pág. 190. 
falsificación de moneda [art 65.1. b) LOPJ] o de tráfico ilícito de estupefacientes, dado el carácter organizado de las actividades delictivas objeto de investigación y sus repercusiones en territorios pertenecientes a diversas Audiencias [art. 65.1.d) i.f. LOPJ] ${ }^{71}$.

Además, en el supuesto en que se solicite la autorización cuando no se hubiera incoado aún instrucción alguna, el Juez de Instrucción deberá comenzarla, al tiempo que autoriza la infiltración. «El único marco procesal admisible para el desarrollo de una infiltración policial es el de una instrucción judicial $»^{72}$.

Por otra parte, cabe destacar que nuestro ordenamiento procesal no sólo prevé un control judicial al inicio de la infiltración, sino que sujeta su desarrollo al control judicial. Así, el párrafo tercero del apartado 1 del artículo 282 bis dispone: «La información que vaya obteniendo del agente encubierto deberá ser puesta a la mayor brevedad posible en conocimiento de quién autorizó la investigación».

Es de destacar la incertidumbre que conlleva la expresión legal «en la mayor brevedad posible», pues cada persona puede tener una apreciación diferente de lo que se considera un breve periodo. Por tanto, debe ser la Jurisprudencia la que concrete en cada caso estos términos.

Este control judicial sobre la actuación del agente encubierto, resulta imprescindible para dar validez a las pruebas obtenidas por éste. Es por ello, por lo que «.... dicha información deberá aportarse al proceso en su integridad y se valorará en conciencia por el órgano judicial competente» (art. 282 bis. 1, párrafo tercero).

Finalmente, cabe resaltar la cláusula de salvaguardia de los derechos del individuo que establece el artículo 282 bis. 3 al establecer: «Cuando las actuaciones de investigación puedan afectar a derechos fundamentales el agente encubierto deberá solicitar del órgano judicial competente las autorizaciones que al respecto establezca la Constitución y la Ley, así como cumplir las demás previsiones legales aplicables».

La autorización judicial previa será exigible en todos aquellos casos en los que la Constitución lo haya previsto de forma expresa ${ }^{73}$, es decir, cuando se trate de restringir los derechos previstos en los artículos 18.2 (inviolabilidad del domicilio), 18.3 (secreto de las comunicaciones), 20.5 (secuestro de las publicaciones) y 22.4 (derecho de asociación $)^{74}$.

71 RIFA SOLER. «El agente encubierto o infiltrado en la nueva regulación de la LECrim» en Revista del Poder Judicial, núm. 55, 1999, págs. 157 y ss.

${ }^{72}$ GASCÓN INCHAUSTI. Op. cit., pág. 191.

73 GÓNZALEZ-CUÉLLAR SERRANO. Op. cit., págs. 109 a 111.

${ }^{74}$ GASCÓN INCHAUSTI. Op. cit., págs. 118 y 119. 


\section{B. El Ministerio Fiscal}

Como se ha expuesto en líneas anteriores, el Juez de Instrucción no es el único facultado para autorizar una infiltración policial, también podrá hacerlo el Ministerio Fiscal «dando cuenta inmediata al Juez» (art. 282 bis. 1 LECrim). Del texto textal no se infiere un reparto de roles y funciones o de ámbitos entre el Juez y el Fiscal. La vaguedad de la expresión legal da a entender que es indiferente la autorización de la infiltración por uno u otro ${ }^{75}$.

La legislación española pretende atribuir un ámbito de decisión autónoma al Ministerio Fiscal, que abarca no sólo su competencia para autorizar la infiltración judicial («dando cuenta inmediata al Juez»), sino también el control sobre el desarrollo de la investigación realizada por el agente encubierto ${ }^{76}$. Así, el artículo 282 bis.1, párrafo tercero dispone que la información que se vaya obteniendo por el agente encubierto deberá ponerse en conocimiento «de quien autorizó la investigación», por tanto, también del Ministerio Fiscal si fue él quien la autorizó.

Sin embargo, el Fiscal no puede «practicar por sí ni ordenar la práctica de medidas restrictivas de derechos fundamentales, con la sola excepción de la detención». Lo que se fundamenta en el principio de proporcionalidad y en el régimen general de restricción de los derechos fundamentales en general y en el ámbito del proceso penal: toda actuación lesiva o restrictiva de un derecho fundamental exige autorización judicial ${ }^{77}$.

Es por ello, por lo que el precepto legal debe interpretarse conforme al principio de proporcionalidad. Cuando se alude a «autorización judicial» o "control judicial» como requisitos para la restricción de derechos fundamentales, no debe interpretarse en forma estricta, es decir, como autorización u control previo. Éstos últimos, como hemos visto, sólo serán exigibles cuando lo establezca expresamente la Constitución y la Ley ${ }^{78}$.

Por eso, es compatible con la Constitución una autorización no judicial (la realizada por el Fiscal) limitativa de los derechos fundamentales, siempre que se prevea un control judicial posterior de dicha autorización ${ }^{79}$.

75 Ibídem, pág. 192.

76 MOLINA MANSILLA. Mecanismos..., cit., pág. 36.

77 GASCÓN INCHAUSTI. Op. cit., págs. 195 y 196.

78 GONZÁLEZ CUÉLLAR SERRANO. Op. cit., págs. 109 y ss.

${ }^{79}$ GASCÓN INCHAUSTI. Op. cit., pág. 196. 
Es conveniente precisar, atendiendo al ámbito procesal en el que se atribuye esta competencia al Ministerio Fiscal, que éste sólo podrá autorizar la infiltración policial en el marco de una investigación preliminar abierta y dirigida por él (conforme a lo previsto en el artículo 785 LECrim) ${ }^{80}$.

Durante el desarrollo de la investigación preliminar, la Policía Judicial se encuentra bajo la dependencia funcionarial del Ministerio Fiscal, es por ello por lo que éste es el competente para autorizar las operaciones policiales de investigación (la infiltración policial o cualquier otra $)^{81}$.

Esta competencia del Fiscal, como apuntábamos, es compatible con los postulados constitucionales dado el control posterior del órgano judicial. Para ello, debe realizarse una interpretación de la expresión legal «dando cuenta inmediata al Juez» que supere la mera interpretación literal de sus palabras.

No se trata de una mera comunicación al juez de la autorización de la medida, sino de la posibilidad de que el juez la revise y dicte una resolución confirmándola, revocándola o modificándola ${ }^{82}$.

Lo que no se precisa en el texto legal la forma de llevar a cabo el posterior control judicial.

A juicio de GASCÓN INCHAUSTI, una vez autorizada la medida por el Fiscal mediante decreto motivado, con un contenido material idéntico al de una autorización judicial, aquél debe remitir todas las actuaciones al juez de instrucción competente, instándole la apertura de diligencias previas para la continuación de la investigación, y la convalidación de la autorización para la infiltración. El plazo máximo para la convalidación o revocación, podrá ser de setenta y dos horas, por analogía a lo dispuesto en el 579. 4 LECrim $^{83}$.

Una vez abierto el proceso penal, la investigación del Fiscal concluye (art. 785 bis.3 de la LECR). La necesidad de solicitar al juez de

${ }^{80}$ En este sentido, se pronuncian entre otros, GIMENO SENDRA et al. Derecho Procesal..., op. cit., págs. 408 y 409. MONTÓN REDONDO, A et al. Derecho Jurisdiccional. III. Proceso Penal, 8. ${ }^{a}$ edición, Valencia, Tirant lo Blanch, 1999, págs. 207 y 208.

${ }^{81}$ GASCÓN INCHAUSTI. Op. cit., pág. 199.

82 RIFA SOLER. Op. cit., pág. 163. LÓPEZ BARJA DE QUIROGA, J. «El agente encubierto» en La Ley, núm. 4778, 1999, pág. 2. DELGADO MARTÍN, J. «El procedimiento penal ante la criminalidad organizada. El agente encubierto» en Actualidad Penal, núm. 1, 2000, pág. 11.

${ }^{83}$ GASCÓN INCHAUSTI. Op. cit., págs. 203 y 204. 
instrucción competente la convalidación de la autorización implica la terminación de la investigación preliminar del Fiscal ${ }^{84}$.

Por todo ello, la información obtenida por el agente encubierto debe remitirse al Juez por ser quién dirige la instrucción, dado que el contenido de aquélla condiciona posteriores investigaciones, y en cada caso concreto, la apertura del juicio oral o el sobreseimiento ${ }^{85}$.

\section{FORMA Y CONTENIDO DE LA AUTORIZACIÓN}

La autorización de la medida se hará mediante auto o decreto según sea autorizada por el Juez de Instrucción o el Ministerio Fiscal, respectivamente ${ }^{86}$, de modo que, cuando sea autorizada por el Ministerio Fiscal, deberá dar «cuenta inmediata al Juez» (art. 282 bis.1 LECrim). La resolución del Juez de Instrucción confirmando o revocando la autorización de la medida por el Fiscal se realizará también mediante auto ${ }^{87}$.

Declara DELGADO MARTÍN ${ }^{88}$ que el auto autorizante podrá contener entre otras, las siguientes formas de control jurisdiccional de la medida:

1. Estableciendo las vías mediante las que el infiltrado debe cumplir su deber de información. A estos efectos, podrá designarse su segundo agente, que puede ser su superior jerárquico, que se encargue de transmitir la información obtenida al juez, cuando exista un riesgo para la integridad física del agente infiltrado.

2. Fijando períodos para trasladar la información que se vaya obteniendo, sin perjuicio de comunicar de forma inmediata la información que sea relevante para la investigación.

3. Delimitando el tiempo de duración de la medida, sin perjuicio de prorrogarla una o más veces, en función de los resultados obtenidos. En el caso de prórroga, la resolución debe contener los mismos requisitos que la resolución autorizante inicial, y que la misma puede denegarse cuando el juez la considere innecesaria.

${ }^{84}$ ORTELLS RAMOS: Op. cit., pág. 111.

${ }^{85}$ GASCÓN INCHAUSTI. Op. cit., pág. 206.

${ }^{86}$ MOLINA MANSILLA. Mecanismos..., cit., pág. 31.

87 GASCÓN INCHAUSTI. Op. cit., pág. 207.

88 DELGADO MARTÍN. La criminalidad..., cit., págs. 93 y 94. 
Particularmente el ordenamiento procesal español dispone en el artículo 282 bis.1 que la resolución en virtud de la cual se autoriza este mecanismo ha de ser fundada y reservada ${ }^{89}$.

Por tanto, tanto el auto judicial como el decreto deben estar fundamentados por la concurrencia de los siguientes elementos ${ }^{90}$ :

1. La existencia de indicios racionales de la comisión de una actividad delictiva organizada a las que se refiere el apartado cuarto del artículo 282 bis LECrim ${ }^{91}$. Corresponde a la Policía Judicial acreditar la existencia de estos indicios, y al Juez o al Fiscal fundamentar suficientemente que concurren en el caso concreto.

2. La medida «resulte necesaria a los fines de la investigación»y que guarde una proporcionalidad con el delito objeto de investigación.

La resolución debe ser además, «reservada y se conservará fuera de las actuaciones con la debida seguridad» (art. 282 bis.1). Se trata de salvaguardar la seguridad de la resolución.

Lo que en opinión de MOLINA MANSILLA es acertado, dado que los autos son públicos para las partes personadas en el proceso concreto, teniendo acceso a toda la información, de modo que para preservar la seguridad del agente encubierto, debe ocultarse su identidad, de modo que sean únicamente los órganos judiciales los que conozcan su identidad, y adoptarse las medidas adecuadas para evitar la infiltración de información ${ }^{92}$.

Respecto de su contenido (que se refleja formalmente en el fallo o parte dispositiva del auto o decreto), deberá hacer referencia a los siguientes extremos ${ }^{93}$ :

1. Actividades delictivas que se sospeche que se han cometido y puedan ser objeto de investigación por el agente infiltrado.

Del artículo 282 bis.1, párrafo primero se desprende que se podrá autorizar la infiltración policial cuando «se trate de investigaciones que afecten a actividades propias de la delincuencia organizada».

${ }^{89}$ MOLINA MANSILLA. Mecanismos..., cit., pág. 29.

${ }^{90}$ GASCÓN INCHAUSTI. Op. cit., págs. 207 y 208.

${ }_{91}$ Cfr. REY HUIDOBRO. El delito de tráfico de drogas. Aspectos penales y procesales, Tirant lo Blanch, Valencia, 2000, pág. 332: «La medida debe reservarse para aquellos supuestos en los que se quiera desmantelar una organización de cierta entidad de la que se tengan sospechas fundadas».

92 MOLINA MANSILLA. Mecanismos..., cit., pág. 33.

93 GASCÓN INCHAUSTI. Op. cit., págs. 208 y ss. 
Tal expresión legal no puede interpretarse como una autorización genérica para la investigación de «delincuencia organizada» Debe especificarse en la autorización el delito (de los previstos en el artículo 284 bis. 4 LECrim) se sospeche se ha cometido y se va a tratar de averiguar mediante este mecanismo.

2. El imputado o imputados objeto de investigación. Debe estar identificado con precisión, o aportarse los datos suficientes que permitan identificarlo.

3. El plazo de duración de la medida, será inicialmente de seis meses, prorrogables.

4. Las facultades que se le atribuyen al infiltrado. Según se deduce del artículo 282 bis. 1 son:

a. Actuar bajo identidad supuesta, participando en el tráfico jurídico y social con tal identidad. Se pretende confundir a los integrantes de la organización delictiva, de modo que les haga suponer que se trata de uno de ellos ${ }^{94}$. Mientras mantenga la identidad falsa está legitimado legalmente para participar en las actividades de la organización delictiva ${ }^{95}$.

b. Adquirir y transportar los objetos, efectos e instrumentos del delito. La actuación del agente se limita a «realizar tareas de auxilio o colaboración por iniciativa del autor, simulando una disposición a delinquir, que permite una más efectiva intervención policial ${ }^{96}$.

La actuación policial será lícita mientras permita el desarrollo de la libre voluntad del sujeto y no suponga una inducción a cometer el delito, en el sentido del artículo 28 a) o de alguna otra forma que lo condicione. Pues en este caso se trataría de un delito provocado ${ }^{97}$.

c. Diferir la incautación de los mismos. Como se puede observar, entre las facultades que se atribuye al agente encubierto, se hace referencia a "comportamientos básicamente pasivos y omisivos, con el fin de evitar conductas activas, que puedan denotar la perpetración de un delito provocado» ${ }^{98}$.

94 STS, Sala $2 .^{\text {a }}$, núm. 4105/2003, de 13 de junio.

95 MOLINA MANSILLA. Mecanismos..., cit., pág. 34.

${ }^{96}$ STS Sala 2. ${ }^{\text {a }}$, núm. 4105/2003, de 13 de junio.

97 STS Sala 2. ${ }^{\text {a }}$, núm. 4107/2003, de 13 de junio.

98 REY HUIDOBRO. Op. cit., pág. 333. 
5. La identidad real y supuesta bajo la que actúa el infiltrado. Cabe precisar, que infiltrado debe ser un funcionario de la Policía Judicial (art. 282 bis.1), el cuál puede llevar a cabo su investigación, mientras se mantenga en vigor la autorización por el órgano competente ${ }^{99}$.

La identidad supuesta será otorgada por el Ministerio del Interior (art. 282 bis. 1), de modo que el Juez de Instrucción o Fiscal se limitan a ratificar la identidad supuesta otorgada previamente por el Ministerio del Interior. La identidad supuesta forma parte del mecanismo de investigación, es la Policía la que propone el nombre o «alias» que utilizará el infiltrado, en el momento de solicitar su autorización al Juez de Instrucción, previa asignación o conformidad del Ministerio del Interior. Aunque el texto legal no lo recoge, es evidente que el Ministerio del Interior y la Policía Judicial facilitaran al infiltrado todos los instrumentos necesarios para operar bajo la identidad supuesta y llevar a cabo la investigación ${ }^{100}$.

En todo caso, es preciso que el Juez de Instrucción o Fiscal sepan quién es el agente concreto propuesto por la Policía Judicial, ya que debe ser posible, que aquéllos denieguen la autorización en función de la persona propuesta. Lo que no será admisible, es que el Juez o Fiscal propongan a un agente para la operación encubierta, ya que ello se prohíbe en el artículo 282 bis.2, párrafo segundo.

\section{DURACIÓN Y PRÓRROGA DE LA INFILTRACIÓN POLÍCIAL}

Una vez otorgada la autorización (o en su caso, ratificada por el Juez la otorgada por el Fiscal) «quedará legitimada la intervención del agente encubierto como instrumento al servicio de la investigación procesal penal». Es sólo a partir de este momento, cuando estará habilitado a darle un carácter investigador a su operación, y adquieren valor probatorio en el proceso penal, las pruebas obtenidas por él ${ }^{101}$.

Ciertamente, como toda diligencia, la investigación realizada a través de la operación encubierta debe estar sometida a un plazo de duración.

\footnotetext{
99 STS Sala 2. a , núm. 3388/2007, de 25 de abril.

100 MOLINA MANSILLA. Mecanismos....., cit., pág. 35.

101 GASCÓN INCHAUSTI. Op. cit., págs. 217 y 218.
} 
1. Duración de la infiltración.

Otro de los temas considerados de gran importancia se refiere a la duración temporal de una operación de infiltración policial, al cual se le ha prestado especial atención por la doctrina especializada ${ }^{102}$. Dado que se trata de una medida excepcional restrictiva de derechos fundamentales, no puede admitirse una duración indefinida y sin controles.

La importancia de la duración temporal debe ser valorada a partir del principio de proporcionalidad. Pues como manifiesta GASCÓN INCHAUSTI permitir una duración excesiva de estas medidas de investigación, puede llegar a ser, dado el caso, desproporcionado en relación con los fines que a través de ellas se pretende alcanzar ${ }^{103}$.

Resulta sumamente complejo establecer a priori, la duración de la operación encubierta, dado que la situación debe valorarse en el caso concreto, atendiendo a múltiples factores ${ }^{104}$.

La duración efectiva de la infiltración de un agente en el entramado de una organización delictiva será evaluada por las Fuerzas y Cuerpos de Seguridad del Estado desde que sea autorizada por el órgano jurisdiccional competente, atendiendo a la necesidad, posibilidad y los riesgos presentes ${ }^{105}$.

Los mandos policiales son los más indicados para determinar y valorar tanto las dificultades de la operación encubierta, los frutos que se pueden obtener y los riesgos para la vida y seguridad del agente ${ }^{106}$.

El plazo inicial de duración de la identidad falsa difiere de un ordenamiento a otro ${ }^{107}$. En nuestro ordenamiento procesal la limitación temporal se deduce indirectamente del texto legal al establecer el plazo de duración de la identidad supuesta ${ }^{108}$.

${ }^{102}$ Vid. GÓMEZ DE LIAÑO FONSECA-HERRERO. Op. cit., pág. 196 y ss. ESPINOSA DE LOS MONTEROS, RZ. El policía infiltrado. Los presupuestos jurídicos en el proceso penal español, Tirant lo Blanch, Valencia, 2010, págs. 355 y ss. GASCON INCHAUSTI. Op. cit., págs. 217 y ss.

103 GASCON INCHAUSTI. Op. cit., pág. 138.

104 DEL POZO PÉREZ. Op. cit., pág. 284.

105 GÓMEZ DE LIAÑO FONSECA-HERRERO. Op. cit., págs. 173 a 175.

106 DEL POZO PÉREZ. Op. cit., pág. 282.

107 Vid. CORREA DE CARVALHO, JT. Tráfico de drogas. Prueba penal y medidas restrictivas de derechos fundamentales, Juruá, Lisboa, 2010, pág. 329. En la mayoría de los ordenamientos que regulan la figura del agente encubierto, como por ejemplo, Brasil, Alemania y Portugal, no se establece duración alguna para el uso de la identidad supuesta, ni para la operación encubierta de agentes en organizaciones delictivas.

108 GÓMEZ DE LIAÑO FONSECA-HERRERO. Op. cit., pág. 196. 
De este modo, el artículo 282 bis. 1 LECrim dispone que: «... La identidad supuesta será otorgada por el Ministerio del Interior por el plazo de seis meses prorrogables de igual duración...». El precepto legal sólo regula la duración de la identidad supuesta otorgada al agente encubierto por el Ministerio del Interior. Lo que sucede es que se aprovecha el quantum del plazo de seis meses concedida por el Ministerio del Interior como límite máximo de la duración inicial de la infiltración ${ }^{109}$.

Conviene recordar que la identidad supuesta es la base de la infiltración policial, por lo que debe entenderse que su plazo de duración máxima, es trasladable a la infiltración policial en sí1 ${ }^{110}$.

Lo anterior no significa que la duración de la infiltración policial, en la medida que está vinculada a la técnica de investigación, sea una cuestión meramente policial. Desde el momento en que las tareas del agente encubierto están al servicio de la investigación procesal penal, se impone el control judicial. Pues, al tratarse de una medida restrictiva de derechos fundamentales, en virtud del principio de proporcionalidad, su duración temporal, concesión de prórrogas y duración de éstas, se atribuye al órgano jurisdiccional ${ }^{111}$.

Además, el legislador al regular las diligencias restrictivas de derechos fundamentales, puede imponer limitaciones temporales que restrinjan el poder discrecional del Juez al cumplir las funciones anteriores ${ }^{112}$.

Es por ello, por lo que en opinión de DELGADO MARTíN los límites temporales establecidos en el precepto deben ser aplicados también por el Juez o Fiscal al autorizar este mecanismo, no pudiendo concederla, en principio, por un plazo no superior a seis meses, pero nada impide

109 ESPINOSA DE LOS MONTEROS. El policía..., cit., pág. 357. En sentido contrario, se manifiesta PAZ RUBIO, JM et al. La prueba en el proceso penal. Su práctica ante los Tribunales, Colex, Madrid, 1999, págs. 400 y 401, al señalar: «La autoridad judicial no está sujeta al plazo que concede la autoridad administrativa sobre la identidad supuesta, sino que el Juez, en función del necesario juicio de proporcionalidad, la información que vaya obteniendo y el curso de la investigación ordenará el cese o la prórroga de la investigación encubierta».

110 GASCÓN INCHAUSTI. Op. cit., pág. 218.

${ }^{111} C f r$. GIMENO SENDRA, V. «Las intervenciones telefónicas en la Jurisprudencia del Tribunal Constitucional y Tribunal Supremo» en Estudios jurídicos en homenaje al profesor Aurelio Menéndez, Civitas, Madrid, 1996, pág. 4436. GÓNZALEZ CUÉLLAR SERRANO, N. Proporcionalidad y derechos fundamentales en el proceso penal, Colex, Madrid, 1990, pág. 174.

112 GASCÓN INCHAUSTI. Op. cit., págs. 218 y 219. 
que pudieran acordarla por un plazo inferior, cuando se exija en el caso concreto por los postulados del principio de proporcionalidad ${ }^{113}$.

De esta forma, al no establecerse en la normativa reguladora un plazo de duración para la infiltración policial, cabe deducir que esta operación perdurará el tiempo que se considere necesario y proporcionado a los fines de la investigación.

El Juez de Instrucción al autorizar o ratificar la medida, establecerá la duración de la misma atendiendo a las recomendaciones de los mandos policiales que diseñaron la operación. Además, el órgano judicial, permanecerá en comunicación con el Ministerio del Interior, para que de forma coordinada, decidir sobre la continuación de la falsa identidad cuando venza el plazo ${ }^{114}$.

Por otra parte, la duración de la medida repercutirá en los riesgos en la operación, de modo que declara DELGADO MARTÍN que cuanto mayor sea el periodo de duración de la operación de infiltración policial, mayores serán las posibilidades de errores por parte del agente, exponiendo su vida y su integridad física, incrementándose también la necesidad de cometer actividades delictivas para mantener la confianza de los integrantes de la organización delictiva, con lo que aumentarán las posibilidades de realizar actos restrictivos de los derechos y garantías fundamentales de los investigados ${ }^{115}$.

Otro factor a destacar es que la infiltración policial no es esporádica, debe prolongarse en el tiempo con el fin de lograr una mínima integración en la organización delictiva que le permita obtener información que puedan servir a los objetivos de la operación. Se requiere un tiempo mínimo para que el agente obtenga la confianza de los integrantes de la organización ${ }^{116}$.

El éxito de estas operaciones encubiertas depende, en gran parte, del «mantenimiento del secreto de la investigación y de una duración razonable, sin duda mayor a un mes» ${ }^{117}$. Declara PAZ RUBIO que dado el silencio legal de un límite máximo, deberá ser el mínimo imprescindible y necesario para el desarrollo de la investigación, pues de lo contrario se vulneraría los derechos de los investigados ${ }^{118}$.

113 DELGADO MARTÍN. «El procedimiento...» cit., pág. 16.

114 GÓMEZ DE LIAÑO FONSECA-HERRERO. Op. cit., pág. 197.

115 DELGADO MARTÍN. La criminalidad..., cit., pág. 61.

116 DEL POZO PÉREZ. Op. cit., pág. 284.

117 GÓMEZ DE LIAÑO FONSECA-HERRERO. Op. cit., pág. 215.

118 PAZ RUBIO. Op. cit., pág. 401. 
Es evidente, que cuanto mayor implicación tenga el infiltrado en la organización, mayores serán las posibilidades de obtener datos relativos a la «estructura, actividades, relaciones y dirigentes de la banda, pero al mismo tiempo aumentará el riesgo real para el Estado de Derecho» de que el agente cometa actividades delictivas, vulnere derechos fundamentales de los investigados e incluso que el infiltrado se convierta en un miembro de la organización, olvidando su función ${ }^{119}$.

2. Prórroga de la infiltración policial.

Conviene precisar en primer lugar, que la prórroga consiste en ampliar el plazo autorizado inicialmente por el Juez de Instrucción competente, para la realización por un agente de una operación encubierta, mediante su infiltración en una organización delictiva.

Nuestro ordenamiento procesal regula la prórroga de la identidad supuesta al disponer que: «La identidad supuesta será otorgada por el Ministerio del Interior por el plazo de seis meses prorrogables por períodos de igual duración...» (art. 282 bis de la Ley de Enjuiciamiento Criminal).

En cuanto en que, la identidad ficticia es inherente a la operación encubierta, se infiere que la duración de la medida de infiltración, será en principio de seis meses, que serán prorrogables indefinidamente $^{120}$. A pesar del tenor literal del precepto, no fue afirmarse que la prórroga de la operación de infiltración sea competencia del Ministerio del Interior ${ }^{121}$.

Transcurrido el plazo de duración inicial de la operación encubierta, corresponde a los mandos policiales valorar, en función de los resultados obtenidos, si es conveniente prorrogarla o no. En el caso, que lo consideren necesario, solicitarán del juez la prórroga de la autorización de la infiltración. Sin esta autorización, la actuación del agente será ilícita ${ }^{122}$.

El Juez examinará la información obtenida y decretará la prórroga cuando de la investigación no se hayan obtenido los resultados esperados o acordará la extinción de la medida, sin prórroga, cuando se hayan satisfecho los objetivos de la investigación ${ }^{123}$.

La concesión de la prórroga, permite además, al Juez de Instrucción verificar, en función de los datos obtenidos y de la información

119 DEL POZO PÉREZ. Op. cit., pág. 282.

120 GASCÓN INCHAUSTI. Op. cit., pág. 221.

121 RIFÁ SOLER. Op. cit., pág. 163.

122 GASCÓN INCHAUSTI. Op. cit., pág. 220.

${ }^{123}$ GÓMEZ DE LIAÑO FONSECA-HERRERO. Op. cit., pág. 215. 
que se espera obtener en el futuro, que este mecanismo sigue siendo respetuoso con los postulados del principio de proporcionalidad ${ }^{124}$.

La competencia para autorizar la prórroga corresponde por tanto, al Juez de Instrucción. Si bien, del precepto pudiera pensarse que la prórroga corresponde al Ministerio del Interior, debe considerarse que prorrogar la identidad supuesta es como prorrogar la infiltración en sí, por lo que la competencia corresponde al órgano jurisdiccional.

En el supuesto de que la medida sea autorizada por el Ministerio Fiscal, ya expusimos, que debe ser confirmada o derogada por el Juez de Instrucción. Siendo éste el destinatario de la información que vaya obteniendo el agente encubierto, y al que previa valoración de las Fuerzas y Cuerpos de Seguridad del Estado, corresponde por tanto, autorizar la prórroga.

Acordada la prórroga por el juez de instrucción, deberá solicitarse al Ministerio del interior la ratificación de la identidad supuesta ${ }^{125}$.

Respecto a la duración de la prórroga, debe trasladarse mutatis mutandis lo señalado para el plazo inicial de la infiltración, por lo que aquella no podrá ser superior a seis meses ${ }^{126}$.

Manifiesta ESPINOSA DE LOS MONTEROS que si la autoridad competente decide que el resultado de la infiltración en la primera fase es fructífero, podrá autorizar la prórroga de la infiltración policial que al igual que la autorización inicial no ha de ser de seis meses, sino que se podrá autorizar por el tiempo que se considere oportuno ${ }^{127}$. Además, al no establecerse en la legislación procesal ningún límite, no hay un número máximo de concesión de prórrogas ${ }^{128}$.

Ello implica que la medida podrá prolongarse el tiempo que se considere necesario a los fines de la investigación, pero al mismo tiempo deberá finalizar cuando deje de responder a los postulados del principio de proporcionalidad ${ }^{129}$.

En este contexto, el criterio de proporcionalidad exige del órgano judicial una resolución motivada sobre la necesidad de ampliar el plazo de duración de la medida ${ }^{130}$.

124 GASCÓN INCHAUSTI. Op. cit., pág. 220.

125 ESPINOSA DE LOS MONTEROS. El policía..., cit., pág. 362.

126 GASCÓN INCHAUSTI. Op. cit., pág. 220.

127 ESPINOSA DE LOS MONTEROS. El policía..., cit., pág. 361.

${ }^{128} C f r$. GASCÓN INCHAUSTI. Op. cit., pág. 221. QUERALT JIMÉNEZ. «Recientes..., cit., pág. 1 .

129 GASCON INCHAUSTI. Op. cit., pág. 221.

130 GÓMEZ DE LIAÑO FONSECA-HERRERO. Op. cit., págs. 196 y 197. 
Cabe precisar que el plazo de prórroga no tiene que ser exactamente el mismo que el concedido en la autorización judicial, sino que su quantum dependerá de las exigencias de la investigación.

Deberá valorarse en cada caso concreto en virtud del principio de proporcionalidad, donde «tendrá destaque un estudio pormenorizado de la idoneidad, de la adecuación, y de la ponderación aplicable». La prórroga deberá sujetarse «al principio de proporcionalidad para evitar la actuación desmedida y arbitraria de los poderes públicos» ${ }^{131}$.

\section{EXTINCIÓN DE LA INFILTRACIÓN}

La primera causa de extinción de esta medida, es la finalización del plazo fijado habiendo obtenido el fin perseguido.

Existen también, otros motivos de extinción de la infiltración policial bien porque la operación no da los frutos esperados, bien porque el juez competente no considere necesario continuar con la infiltración policial para conseguir el objetivo ${ }^{132}$.

Además, la autorización para la infiltración policial se extinguirá, quedando sin validez la diligencia cuando concurra alguno de los supuestos que se exponen a continuación ${ }^{133}$ :

a. Autorizada por el Fiscal, no se dé cuenta inmediata de ella al Juez de Instrucción competente; o dando cuenta, el Juez decida revocar la autorización de la infiltración.

b. Se deniegue la prórroga de la autorización por el Juez, cuando de los datos obtenidos de la operación encubierta, y de la solicitud de prórroga se deduzca que:

- De la investigación no se ha obtenido, ni cabe esperar que se obtenga, ningún fruto significativo ${ }^{134}$.

- Han desaparecido los indicios delictivos por los que se autorizó la medida, o los únicos existentes se refieran a delitos que no se cometan organizadamente, o que se trate de delitos no encuadrables en el apartado cuarto del artículo 282 bis.

— El agente encubierto no opere dentro de los límites legales.

131 ESPINOSA DE LOS MONTEROS. El policía..., cit., pág. 362.

132 Ibidem, pág. 363.

133 GASCÓN INCHAUSTI. Op. cit., págs. 223 a 225. En el mismo sentido, se pronuncia NUÑEZ PAZ/GUILLÉN LÓPEZ. Op. cit., págs. 129 y 130. ESPINOSA DE LOS MONTEROS. Op. cit., págs. 363 y ss.

134 NUÑEZ PAZ/GUILLÉN LÓPEZ. Op. cit., pág. 129. 
c. Se cancele de oficio por el Juez la autorización, cuando de la información que le suministre el agente se acredite alguno de los extremos expuestos anteriormente.

d. Cuando el agente encubierto o los mandos policiales que supervisan su función consideren que la investigación no está aportando los resultados esperados o que ha devenido imposible la infiltración dentro de la organización. En este caso, el agente podrá ponerle fin, o sus mandos policiales podrán ordenarle que lo haga ${ }^{135}$.

e. Lo anterior se aprecia de forma más evidente cuando exista un grave riesgo para la vida del agente, pudiendo abandonar el mismo la operación, y podrán ordenar también sus mandos policiales que lo haga.

En síntesis, en todas las causas de extinción de la infiltración policial, existe un coherente respeto a las exigencias del principio de proporcionalidad $^{136}$.

En todo caso, manifiesta ESPINOSA DE LOS MONTEROS ${ }^{137}$ que cuando el Juez de Instrucción decide cerrar la operación encubierta sin la obtención de elementos probatorios que permitan condenar a los integrantes de la organización criminal, mediante su aportación al correspondiente proceso penal, se origina el sobreseimiento de la causa.

Sobreseimiento que podrá ser libre conforme a las causas establecidas en el artículo 637 de la LECrim, o bien provisional en virtud del artículo 641 LECrim, salvo que en este último supuesto se emplee otros mecanismos de investigación.

\section{RESPONSABILIDAD PENAL DEL AGENTE ENCUBIERTO}

Como ya se expuso en líneas anteriores, la operación de infiltración policial implica no sólo la restricción de derechos fundamentales para los sujetos investigados, sino ciertos reparos desde la perspectiva del principio de legalidad, ya que a través de ella se legitima al agente a cometer o participar en la comisión de delitos. No obstante, el agente no podrá cometer más delitos que aquellos que resulten necesarios

135 Ibidem, pág. 129, señalan los autores que en estos supuestos no será necesario que el órgano jurisdiccional dicte resolución que deje sin efecto formal la autorización.

136 GASCÓN INCHAUSTI. Op. cit., pág. 125.

137 ESPINOSA DE LOS MONTEROS. El policía..., cit., pág. 364. 
a los fines establecidos y dentro de ciertos límites ${ }^{138}$. Y siempre que obedezcan al principio de proporcionalidad ${ }^{139}$.

Para una adecuada comprensión de la posible responsabilidad penal del infiltrado conviene precisarse que la admisión legal de esta figura, no debe interpretarse como la introducción de una figura del «agente autorizado para delinquir» sino la aceptación de una operación policial necesaria para simular actividades delictivas de cooperación, engañando a los integrantes de la misma, con el fin de obtener pruebas contra la organización ${ }^{140}$.

El agente encubierto utiliza «maniobras de inteligencia policial» como el uso del «engaño y de la disimulación» utilizando una identidad falsa, con el fin de obtener la confianza de los integrantes de la organización conlleva a la comisión casi obligatoria de delitos ${ }^{141}$.

La LECrim regula simultáneamente la exención de responsabilidad penal del agente encubierto y los límites de su impunidad en el artículo 282 bis. 5, párrafo primero: «El agente encubierto estará exento de responsabilidad criminal por aquellas actuaciones que sean consecuencia necesaria del desarrollo de la investigación, siempre que guarden la debida proporcionalidad con la finalidad de la misma y no constituya una provocación al delito».

Es criticable la redacción del precepto en cuanto que no precisa que debe entenderse por la expresión legal «debida proporcionalidad» necesaria para que el agente infiltrado no incurra en responsabilidad penal, sometiéndose por tanto, a la valoración judicial posterior ${ }^{142}$.

Este precepto es una norma penal sustantiva en la que se regula una exención de responsabilidad penal a pesar de que alguna de las conductas del infiltrado sean subsumibles en algunos tipos penales ${ }^{143}$. Su encuadramiento en la LECrim no es desacertado ${ }^{144}$, dado que sirve para delimitar el ámbito de actuación de las autoridades de persecución penal cuando se emplea esta medida ${ }^{145}$.

138 GASCÓN INCHAUSTI. Op. cit., págs. 273 y 274.

139 GÓMEZ DE LIAÑO FONSECA-HERRERO. Op. cit., pág. 258.

140 REDONDO HERMIDA, A. «El agente encubierto en la jurisprudencia española y en la doctrina del Tribunal Europeo de Derechos Humanos» en Revista de derecho penal, procesal y penitenciario, núm. 45, 2008, pág. 100.

${ }^{141}$ ESPINOSA DE LOS MONTEROS. El policía..., cit., págs. 194 y 195.

142 RODRÍGUEZ FERNÁNDEZ. Op. cit., pág. 106.

143_CHOCLÁN MONTALVO. Op. cit., pág. 64.

${ }^{144}$ No obstante, considera LÓPEZ BARJA DE QUIROGA, J. «El agente encubierto» en La Ley, núm. 4778, 1999, pág. 2, que hubiera sido más correcta su ubicación en el Código Penal, y no encuentra explicación suficiente a su regulación en la LECrim. 145 GASCÓN INCHAUSTI. Op. cit., pág. 276. 
Sin embargo, las consecuencias procesales de artículo 282 bis. 5 son reducidas, pues se regula la responsabilidad del agente encubierto como infiltrado, pero no persigue definir los límites de la licitud o ilicitud probatoria. La ilicitud probatoria y la punibilidad del agente infiltrado no aparecen forzosamente unidas. Es posible que una determinada actividad del agente sea lícita, y sin embargo, la prueba obtenida a través de ella no sea válida, por constituir una vulneración de los derechos fundamentales ${ }^{146}$.

Las actividades lícitas e ilícitas del infiltrado deben tener, por tanto, como límite el respeto a los derechos fundamentales de las personas, especialmente las que son investigadas.

En cuanto a su naturaleza jurídica, cabe afirmar que el precepto consagra una causa de justificación, que excluye la antijuricidad de la conducta del agente encubierto. Se ampara su conducta en la causa prevista en el artículo 20. 7 del Código Penal: «El que obre en el cumplimiento de un deber o en el ejercicio legítimo de un derecho, oficio o cargo ${ }^{147}$.

En este sentido, la LECrim permite y acepta la comisión de determinados ilícitos penales por parte del agente, siempre que concurran los siguientes requisitos ${ }^{148}$ : que sea consecuencia necesaria del desarrollo de la investigación; que sean proporcionales con la finalidad de la investigación; que no constituyan una provocación al delito. Si bien, conviene precisar que el texto legal utiliza aquí de forma impropia el término provocación, debe interpretarse que se está refiriendo a la inducción del delito.

Lo que el texto legal trata de evitar es que el infiltrado adopte un papel protagonista en la organización delictiva, asumiendo la autoría intelectual en la planificación de actividades delictivas no previstas de forma autónoma por los investigados.

Por tanto, para que la actuación delictiva del agente encubierta esté exenta de responsabilidad penal deben concurrir simultáneamente y de forma inexcusable los requisitos expuestos ${ }^{149}$. La autorización para actuar como agente encubierto está penalmente protegida, siempre que no se vulneren abusivamente los derechos fundamentales y se

146 Ibídem, pág. 277.

147 En este sentido, se pronuncian entre otros, RIFÁ SOLER. Op. cit., pág. 172. REY HUIDOBRO. El delito de tráfico..., cit., pág. 335.

${ }_{148}$ GASCÓN INCHAUSTI. Op. cit., págs. 278 y ss. En el mismo sentido, se pronuncia SÁNCHEZ TOMÁS. Op. cit., pág. 215. CHOCLÁN MONTALVO. Op. cit., pág. 64.

149 GÓMEZ DE LIAÑO FONSECA- HERRERO. Op. cit., pág. 258. 
actúe dentro de los límites de la autorización y en la medida que resulte totalmente necesario para la obtención de información ${ }^{150}$.

\section{CONCLUSIONES}

La lucha contra la criminalidad organizada, especialmente en el marco del narcotráfico y el terrorismo, es una materia ardua y compleja.

Las dificultades para desarticular esta compleja estructura organizativa de cara a la prevención y a la persecución de los delitos que forman parte de su actividad criminal, y el descubrimiento de sus máximos responsables, son enormes. Tales dificultades se agravan en la actualidad por el proceso de globalización -actuación en diversos Estados-, por el entramado de tales redes organizativas, el empleo de tecnologías cada vez más sofisticadas, y la clandestinidad con la que actúan.

Ante este nuevo reto, surge la necesidad de articular nuevos mecanismos de investigación criminal que permitan combatir eficazmente esta forma de criminalidad. Estos nuevos mecanismos, muy especialmente la figura del agente encubierto analizada en el presente trabajo, deben ser respetuosas con los principios básicos del derecho penal y procesal -fundamentalmente el principio de legalidad, proporcionalidad y control judicial-, y tener siempre presente la supremacía de los derechos y garantías que la Constitución reconoce a todo imputado.

De esta forma, las actuaciones del agente encubierto están sometidas a límites infranqueables. Las actuaciones que en el transcurso de la investigación se desarrollen fuera de estos límites, de las previsiones legales y al margen de la Constitución, afectarán a la validez procesal de las pruebas obtenidas mediante esta diligencia policial, no pudiendo aportar sus resultados en el proceso penal; independientemente de la responsabilidad en la que puede incurrir el agente por sobrepasar su ámbito de actuación legítima.

150 REDONDO HERMIDA. Op. cit., pág. 101. 